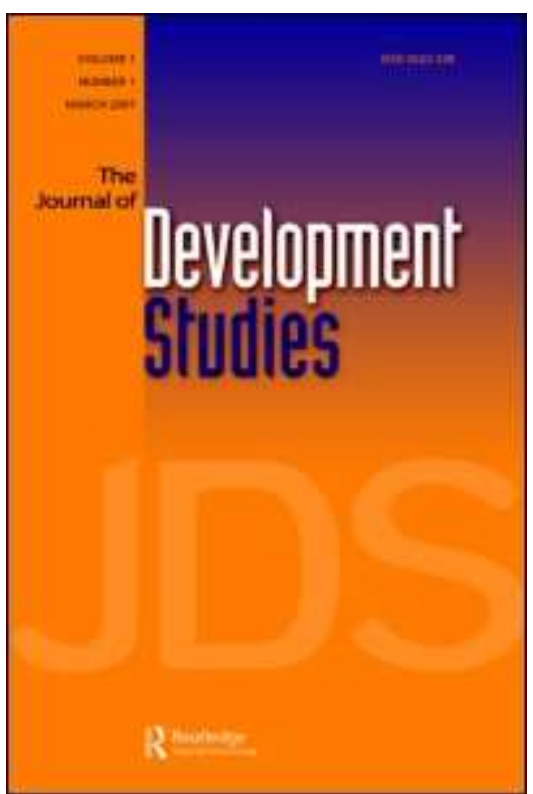

\title{
Government Effectiveness and Regional Variation in Informal Employment
}

\begin{tabular}{|r|l|}
\hline Journal: & Journal of Development Studies \\
\hline Manuscript ID: & FJDS-2010-Sep-0040.R2 \\
\hline Manuscript Type: & Original Manuscripts \\
\hline Keywords: & $\begin{array}{l}\text { informal employment, government effectiveness, Latin America }< \\
\text { Geographical Area, Brazil }\end{array}$ \\
\hline \multicolumn{2}{|c}{} \\
\hline
\end{tabular}

\section{SCHOLARONE ${ }^{\text {th }}$ Manuscripts}


This paper analyses the role of government effectiveness in the determination of informal employment. A theoretical model is developed, in which local governance and worker skill level are assumed to influence the decision of the worker whether to seek employment in the formal or informal sector. The model is assessed empirically using data from Brazil, where almost half of the urban labour force is employed informally. The empirical analysis supports the predictions of the model and suggests that the probability of a worker being employed informally is lower in regions with better governance and higher average education.

\section{Introduction}

Widespread informal employment continues to be a salient feature of labour markets in developing countries. In their comprehensive study of informality in Latin America, Perry et al. (2007) estimate the share of the labour force employed informally to range from about 20 per cent in Chile to about 80 per cent in Paraguay. Despite economic growth, recent evidence suggests that informal employment has not declined in developing countries over the past two decades (Freeman, 2009).

The defining characteristic of informal employment is usually that it is not regulated in any formal employment contract, and therefore is not subject to labour market regulations. To the worker, this implies being outside most social security arrangements while faced often with low compensation 
and poor working conditions (Jütting et al., 2008). For businesses, being informal constrains the ability to raise financial capital and to enforce complex contracts, which is likely to restrict their prospects of growing (Loayza, 1996; Fajnzylber et al, 2009; Hansen et al, 2009). To the economy as a whole, wide-spread informality means difficulties in collecting tax revenues for the provision of public goods and services. Recent empirical evidence even suggests that informality affects economic growth negatively, controlling for other country characteristics (Loayza et al., 2010).

A relatively large theoretical and empirical literature has sought to identify the determinants of informality, both in terms of worker and firm characteristics, on the one hand, and the burden of formal rules and regulations on the other hand. Empirical evidence also suggests that the manner in which governments choose to enforce regulations is important for the degree of informality in a country. Friedman et al. (2000), for example, in a study including 67 countries, suggest that high taxes per se do not drive businesses into the informal sector. Instead, it is the discretion in the application of rules and the corresponding corruption that it generates that seems to make businesses escape the formal economy.

This paper adds to this branch of literature by assessing the role of government effectiveness in determining the probability of informal employment among Brazilian workers. Government effectiveness is understood here as the extent to which the government supports and implements formal institutions and provides high-quality public goods and services. It corresponds closely to the definition given by Kaufmann et al. (2009). Jonasson (2011) reports a negative correlation between government effectiveness and the size of the informal sector among Brazilian municipalities. This paper extends on those findings by developing a theoretical model, which incorporates government effectiveness in the worker's decision of whether to participate in the formal or informal sector. The model is evaluated empirically using Brazilian worker-level data. Among Brazil's over 5500 municipalities, informality varies between 20 and 80 per cent when measured as the share of the urban labour force lacking a signed labour card. This wide range of informality among municipalities suggests that labour and tax regulations, which are determined largely at the national level, are far from the only determinants of informality in a country. By using municipal data on public sector 
management and a range of other indicators, and keeping country-specific characteristics fixed, the effects of government effectiveness are assessed.

\section{Related literature}

This paper relates primarily to the literature on institutional determinants of informal economic activity. Institutional determinants refer here both to formal institutions, such as labour and tax regulations, and informal institutions, such as social norms of tax compliance (Casson et al., 2010). Informal economic activities include any market-based legal production of goods and services, deliberately hidden from authorities to avoid taxation or costly regulation, and also working, or hiring labour, without an employment contract complying with labour market regulations. There is a large literature on the determinants of informality (reviewed by Kucera and Xenogiani, 2009; Perry et al., 2007; and Schneider and Enste, 2000) and a growing literature on how various notions of governance and social norms shape economic development and other aspects of society. Most such studies, however, focus on economic growth as the outcome of interest (e.g. Glaeser et al., 2004; Hall and Jones, 1999). Relatively few studies from these two branches of literature are concerned specifically with the role of government effectiveness in shaping the informal sector. The empirical evidence that exists is to a large extent at cross-country level and little work has been done at the sub-national or micro level.

Empirical cross-country evidence by Johnson et al. (1998) and Friedman et al. (2000) suggests that the unofficial economy tends to be larger, not where taxes are higher, but in countries where the regulatory burden is higher, corruption is more wide-spread, and where the rule of law is weaker. Loayza et al. (2006), for a sample of about 70 countries, find that the level of business regulation is on its own correlated positively with informality but when quality of governance is interacted with the level of regulation, regulation is negatively related with informality. Loayza et al. (2010) analyze a broader set of determinants of informality for a sample of about 85 countries and find that informality is negatively related with law and order, business regulatory freedom, and with schooling achievement. Restricting the focus to Latin America, "policy and institutional variables related to the quality of the state are the most important factors explaining the differences in informality" (Loayza et 
al., 2010, p. 179). Torgler and Schneider (2009) add tax morale to the set of explanatory factors for cross-country variation in informality; various indicators of good governance relate negatively to the size of the shadow economy, but also the willingness of citizens to pay taxes is related negatively with the size of the shadow economy. While the use of various indicators of quality of governance has been questioned (Langbein and Knack, 2010), it is probably fair to conclude from the above studies that it is not only the design of formal rules and regulations that determines the size of the informal sector, but also the manner in which they are implemented and obeyed.

At sub-national level, there are a few empirical studies concerned with regional variation in the size of the informal sector, e.g. Chaudhuri et al. (2006) on 14 states in India and Torgler and Schneider (2007) on the 26 cantons of Switzerland. At the micro level, few empirical studies analyse the effect of institutional factors on the propensity of workers or businesses to participate in the informal sector. A recent exception is the study by Almeida and Carneiro (2009), who analyse how differences in enforcement of labour regulation across regions in Brazil affect regional informal employment and unemployment. They find evidence that stricter enforcement in a region, measured as the aggregate amount of registration fines issued, leads to less informal employment but also to higher unemployment. Empirical studies at the micro level otherwise tend to be concerned primarily with worker characteristics as explanatory factors of informal employment. These studies generally conclude that the probability of working in the informal sector decreases with human capital endowment measured by years of education, job tenure, and experience (Funkhouser, 1996; Gong et al., 2004; Marcouiller et al., 1997).

In sum, empirical evidence at the cross-country level suggests that corruption and low quality of governance, as well as and low tax morale, seem to cause informality to a greater extent than strict labour regulation and high taxes. Empirical evidence at the micro level provides strong evidence that worker-specific characteristics fundamentally affect the probability of working in the formal or informal sector. Less is known about the causes of regional variation in informality within countries. The fact that it varies considerably across regions suggests that region-specific characteristics could be at least, or even more, important determinants of informality than labour and tax regulations and other nation-wide formal institutions. 


\section{Theoretical framework}

In this section, a static model is developed to explain regional variation in informal employment. The proposed determinants of such variation are regional differences in worker skill distribution, tax rates and government effectiveness. The model is inspired by Loayza and Rigolini (2011), Galiani and Weinschelbaum (2010), and to a lesser extent by Rauch (1991), the principal novelty of the model being the inclusion of government effectiveness as a factor influencing the worker's decision on sector of employment. The basis of the model is a two-sector framework of occupational choice, in which the worker chooses sector depending on expected earnings. The two sectors of employment here are the formal and the informal sector.

Consider first the case in which the worker only takes into account expected income when choosing sector of employment. Utility is assumed to increase monotonically in income, so that the worker maximizes expected utility by choosing to work in the sector that gives the highest expected income. The decision to work is pre-determined outside the model; hence the consumption/leisure decision is abstracted from. The utility maximisation problem reduces to:

$$
\max _{j} U\left(y^{i}\right), \quad j=(F S, I S)
$$

where $y^{j}$ is expected labour income in sector $j$. Workers are assumed to differ by skill endowment $s$, which is distributed among workers according to some density function $h(s)(0 \leq s \leq 1)$. Skill endowment determines the productivity of the worker, measured in number of homogenous labour units, $L(s)$. The formal sector (FS) and the informal sector (IS) are assumed to differ from each other in several aspects, affecting the expected income and hence the incentives faced by the worker in the choice of sector.

First, the institutional arrangements in the formal sector are assumed to allow for higher labour productivity than in the informal sector. The better the local government serves its citizens (i.e. the higher the level of government effectiveness), the wider is the labour productivity gap between 
sectors. The model allows for different channels through which this takes place. A broad interpretation is that, with formal institutions that are well implemented and enforced by the government, firms face better prospects for benefiting from economies of scale through cheaper access to capital and better ability to enforce complex contracts (de Paula and Scheinkman, 2010; Straub, 2005). As a consequence, production in the formal sector will be more capital intensive on average, hence increasing the productivity of labour. A narrower interpretation is that local governments can supply public services and support institutions that directly affect labour productivity, independently of production technology, in an efficiency-wage manner. It could be that the worker is more productive in the formal sector due to an increased sense of transparency, security, and stability in the work environment of the formal sector, compared to the informal sector.

Let labour productivity be characterized by positive but diminishing returns to worker skill in both sectors. In the informal sector, labour productivity, measured in units of units of homogenous labour $(L)$, is given by:

$$
L^{H S}(s)=s^{\alpha} \quad(0<\alpha<1)
$$

If $g$ denotes the local level of government effectiveness, then labour productivity in the formal sector is given by:

$$
L^{F S}(s, g)=(1+g) s^{a} \quad(-1<g<1)
$$

Second, assume that income is taxed at local rate $t$ in the formal sector. While workers in the informal sector do not pay taxes, they face a risk of being caught by the authorities for working informally (or for their employers hiring them informally). In case of detection, labour income will be zero. The risk of being caught, $c$, is determined by the strength of the enforcement of tax and labour regulation $e$ $\left(0<c<1 ; e>0 ; c^{\prime}(e)>0\right)$. Expected income in the informal sector is given by:

$$
y^{I S}=[1-c(e)] s^{\alpha}
$$


Third, expected income in the formal sector is affected by the worker's probability of finding a job in that sector and thereby gaining the corresponding productivity enhancement. The worker's perceived probability of obtaining a job is an increasing function of skills, given by: ${ }^{1}$

$$
\pi(s)=s^{\beta} \quad(0<\beta<1)
$$

The formal and the informal sectors are assumed to be integrated in the sense that one unit of homogenous labour, $L$, is paid the same in both sectors. For simplicity, assume that the worker faces a perfectly elastic labour demand at a price equal to one. ${ }^{2}$ Imposing labour income tax rate $t(0<t<1)$, the expected net income in the formal sector is:

$$
y^{F S}=(1-t)(1+g) s^{\alpha+\beta}
$$

The threshold level of skill that equates the expected incomes $y^{I S}$ and $y^{F S}$ in the two sectors is:

$$
\underline{s}=\left[\frac{1-c}{(1-t)(1+g)}\right]^{\frac{1}{p}}
$$

Whenever the skill level falls short of $\underline{s}$ the individual does not expect to benefit from participating in the formal sector. Given that workers choose the sector rationally (and do not attach utility or disutility to any of the sectors beyond labour income), $y^{I S}(\underline{s})=y^{F S}(\underline{s})$ denote the highest expected earnings in the informal sector and the lowest in the formal sector, respectively, for given levels of $t, g$ and $c$. The existence of a formal sector requires that $\underline{s}$ is less than 1 , or:

$$
y \equiv \frac{(1-t)(1+g)}{(1-c)}>1
$$

where $\gamma$ denotes the ratio of formal to informal income for the highest educated (for whom $s=1$ ).

The higher the skill threshold, the higher is the probability that any given worker will prefer to work in the informal sector. Differentiating (7) with respect to $t, g$, and $c$ shows that the propensity to work informally increases with $t$ and decreases with $g$ and $c$. Figure 1 provides an illustration of these 
effects. Below the skill threshold $\underline{s}_{0}$ the worker expects to earn more by being in the informal sector than in the formal sector, depicted by the segment of the $y_{0}{ }^{I S}$ curve above the $y_{0}{ }^{F S}$ line. The reason for this is the low perceived probability for low-skilled workers to find a formal job. ${ }^{3}$ The effect of an increase in law enforcement, which increases $c$, is shown by the lowering of the informal-sector income curve from $y_{0}{ }^{I S}$ to $y_{1}{ }^{I S}$, which decreases the skill threshold from $\underline{s}_{0}$ to $\underline{s}_{1}$. On the other hand, an increase in the tax rate or a decline in government effectiveness lowers the formal-sector income curve from $y_{0}{ }^{F S}$ to $y_{1}{ }^{F S}$, increasing the skill threshold from $\underline{s}_{0}$ to $\underline{s}_{2}$.

\section{[Figure 1]}

The share of the labour force that works in the informal sector in region $m$ is given by:

$$
I S_{m}=H_{m}\left[\underline{s}_{m}\left(g_{m}, t_{m}, e_{m}\right)\right]=\int_{0}^{S m} \boldsymbol{h}_{m}(s) d s
$$

where $H_{m}(s)$ is the cumulative density function of skill endowments $s$ in regional $m$. Thus, the model predicts that regional differences in the relative size of the informal sector are determined by regional differences in the quality of institutions $g$, the tax rate $t$, the risk of income loss in the informal sector $c$, and in the skill distribution in the local labour force, $h_{m}(s)$. Moreover, given the levels of $t, g$, and $c$, informality will be higher (lower) in regions with lower (higher) average level of skill.

The model described thus far does not predict that there could be an overlap between the sectors in skills and/or earnings, i.e. that some workers in the informal sector are more skilled and earn more than some workers in the formal sector. Such an overlap has been found to be extensive in several empirical studies (Bosch et al., 2007; Maloney, 2004) and is evident also in the case of Brazil (Table 1, below). One explanation for such a sectoral overlap is the existence of worker-specific nonpecuniary costs and benefits of participation in the informal sector. Non-pecuniary benefits of working in the informal sector could be a higher degree of flexibility in working hours or a greater sense of freedom and independence (Maloney, 2004; Marcouiller, et al., 1997). A perceived cost of informal work could be the sense of insecurity about one's livelihood, in terms of future earnings, 
where $\hat{y}^{j}$ denotes total expected benefit of employment in sector $j$. Let $b(x)$ denote the net value of the non-pecuniary benefits and costs for the worker of being in the informal sector $(-1<b<1), x$ denoting worker characteristics affecting the valuation of these net benefits. Assume that $b$ is proportional to income such that the sum of benefits in the informal sector is:

$$
\hat{y}^{I S}=[1+b(x)] y^{I S}=[1+b(x)] \times[1-c(e)] s^{\alpha}
$$

The worker skill threshold equating total benefits in the informal sector with income in the formal sector, $\hat{s}$, is given by:

$$
s=\left[\frac{(1-c)(1+b)}{(1-t)(1+g)}\right]^{\frac{1}{\beta}}
$$

The qualitative effects of changes in $t, c$, and $g$ are the same as in the case without non-pecuniary benefits. The additional effect to note is the positive relationship between the threshold level $\hat{s}$ and the net benefits $b$.

Figure 2 illustrates situations in which the worker experiences zero, positive, and negative net benefits in the informal sector. For given levels of $t, c$, and $g$, let $\hat{s}_{0}$ be the skill threshold in the case when the net benefit $b$ is zero. If a worker values the net benefit by $b_{1}>0$, then the total benefit in the informal sector is given by the $\hat{y}^{I S}{ }_{1}$ curve, which lies above the $y^{I S}$ curve. The $\hat{y}^{I S}{ }_{1}$ curve intersects the formal sector income curve, $y^{F S}$, at $\hat{s}_{1}>\hat{s}_{0}$. The worker's monetary income in the informal sector at $\hat{s}_{1}$, $y^{I S}\left(\hat{s}_{1}\right)$, is lower than the income she expects to earn in the formal sector with the same skill level, $y^{F S}\left(\hat{s}_{1}\right)$. Due to the non-pecuniary benefit, however, she is indifferent between the two sectors at this 
skill threshold. If, instead, a worker experiences a negative net benefit $b_{2}<0$ of participating in the informal sector, then the total benefit curve falls below $y^{I S}$ and the skill threshold decreases from $\hat{s}_{0}$ to $\hat{s}_{2}$. Despite the fact that $y^{I S}\left(\hat{S}_{2}\right)$ is higher than $y^{F S}\left(\hat{s}_{2}\right)$, the worker is indifferent between the two sectors at this point, due to the disutility attached to work in the informal sector.

[Figure 2]

Given that $b$ is individual specific, there will be an entire distribution of thresholds $\hat{s}$ within each region. Let $s^{*}=s-\hat{s}$, so that whenever $s^{*}$ is below 0 , the individual works in the informal sector. If the distribution of $s^{*}$ is given by $k\left(s^{*}\right)$, the size of the informal sector in region $m$ is given by:

$$
I S_{m}\left[k_{m}\left(s^{*}\right)\right]=\int_{-1}^{0}\left[k_{m}(s]^{*}\right) d s^{*}
$$

The empirical analysis in the remainder of the paper is concerned with testing the hypothesis of negative effects of skills levels and government effectiveness on informality, using proxy variables to allow for non-pecuniary benefits.

\section{Empirical approach}

The theoretical model is evaluated using worker-level and municipal data from Brazil. A binomial probability model is estimated at worker level to assess the extent to which the individual and local factors considered in the model correlate with the probability of having informal employment. To start with, all explanatory variables are assumed to be exogenous. This assumption is then relaxed, using an instrumental variable (IV) approach to adjust for the potential endogeneity of local government effectiveness.

The binomial probability model is estimated using a probit model. The difference $s^{*}$ between the worker's skill level $(s)$ and her participation threshold $(\hat{s})$ enters the probability model as an unobserved latent variable. By assumption, worker $i$ participates in the informal sector if and only if 
$s_{i}^{*}$ is below zero. Thus, if $s_{i}^{*}$ is determined by the set of exogenous variables under consideration, then the probability that the individual participates in the informal sector is given by:

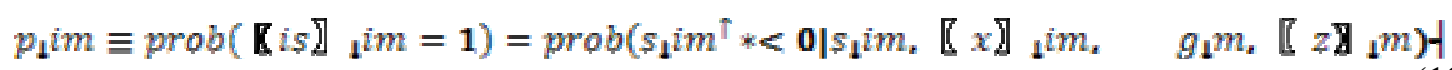

The binary variable $i s_{i m}$ equals one if the individual works in the informal sector and zero if in the formal sector (subscript $m$ denoting municipality). $s_{i m}$ is a set of proxies for worker skills; $x_{i m}$ is a vector of other individual characteristics that are assumed to affect productivity and the individualspecific valuation of the non-pecuniary net benefit in the informal sector; $g_{m}$ is a set of proxies for government effectiveness; and $z_{m}$, finally, consists of local productivity shifters that might affect the relative productivity in the formal and informal sectors. The probability model is estimated under the assumption that $s_{i m} *$ is a linear function of the exogenous variables:

$$
s_{i m}^{*}=s_{i m} \beta_{s}+x_{i m} \beta_{x}+g_{m} \beta_{g}+z_{m} \beta_{z}+u_{i m}
$$

where the $\beta$ s denote vectors of parameters to be estimated and $u_{i m}$ denotes a residual that is assumed to be normally distributed with zero mean and variance $\sigma^{2}$. Let $F_{u}$ denote the cumulative distribution function of $u$. The probit model then gives:

$$
\hat{p}_{i m}=1-F_{u}\left(s_{i m} \hat{\beta}_{z}+x_{i m} \hat{\beta}_{x}+g_{m} \hat{\beta}_{g}+z_{m} \hat{\beta}_{z}\right)
$$

where $\hat{p}_{i m}$ denotes the estimated $p_{i m}$ and the $\hat{\beta}_{\mathrm{S}}$ are the estimated coefficients $(0 \leq \hat{p} \leq 1)$.

If the variable representing government effectiveness is correlated with the error term $u_{i m}$ in (14), the coefficient estimate will be biased. Such correlation could be due to unobserved regional factors, such as culture or aspects of economic development not captured in $z_{m}$, that affect government effectiveness while also affecting the probability that a worker is employed informally. In the IV probit approach, a set of instrumental variable candidates are used in order to remove the potential bias in the coefficient estimate for government effectiveness. The model above is extended as follows. To simplify the notation, let $\boldsymbol{X}$ denote the set of all exogenous variables in (14), excluding government 
effectiveness, $G E$, which is now assumed to be endogenous. Let $\boldsymbol{\beta}$ denote the set of all corresponding coefficients. Finally, let $\boldsymbol{Z}$ denote the set of instrumental variables. The IV probit model estimates:

$$
\begin{aligned}
& s_{i m}^{*}=\boldsymbol{X}_{i m} \boldsymbol{\beta}+G E_{i m} \beta_{G E}+u_{m} \\
& G E_{i m}=X_{i m} \pi_{X}+Z_{i m} \pi_{Z}+v_{i m}
\end{aligned}
$$

where $\boldsymbol{\pi}_{X}$ and $\boldsymbol{\pi}_{\mathrm{Z}}$ denote vectors of coefficients in the reduced-form estimation of $G E$. By assumption, $\left(u_{i m}, v_{i m}\right) \sim N(0, \Sigma), \Sigma$ denoting the variance-covariance matrix. Similar to the probit model, the IV probit model (16) is estimated by maximum likelihood.

\section{Data and descriptive statistics}

The main data source used for the empirical analysis is the Brazilian Demographic Census for the year 2000. All worker-level information is derived from these data, and several of the municipallevel variables are aggregated from them as well. The publicly available sample of the Census data includes almost 20 million individual observations, which makes it representative at the level of the municipality. In total, there were 5507 municipalities in the year 2000, with an average population of about 30000 people. The Census data provide detailed information on employment status, earned income and a range of socioeconomic variables. To get the relevant information about municipalities, two data sources are used in addition to aggregates derived from the Census: Base de Informações Municipais between 2000 and 2006 and Perfil dos Municípios Brasileiros - Gestão Pública, 20052006, both from the Brazilian Institute of Geography and Statistics (IBGE). These databases contain detailed information on the structure of the local economy, various demographic characteristics and indicators of public sector management at the municipal level.

\subsection{The informal sector in Brazil}

The definition of the informal sector used in this paper is based on the employment categories defined in the Demographic Census. Informal employment is defined as being an unregistered 
employee, a self-employed person (not contributing to a social security institution), or an employer who has fewer than five employees and does not contribute to any social security institution. ${ }^{4}$ Unpaid workers (who constitute about 5\% of the informal sector) are excluded from the empirical analysis. Only the urban labour force is analyzed in this study, mainly because the majority of rural residents are engaged in agriculture and do not have access to either a formal or an informal labour market to the same extent as in urban areas. Using this definition, $45 \%$ of the urban labour force in Brazil is informal. Approximately $60 \%$ are employees and about $40 \%$ are self-employed in the informal sector.

The informal sector in Brazil has some of the characteristics that are commonly observed in studies concerned with informal employment in Latin America and elsewhere. Table 1 provides some key indicators. First, labour incomes are on average considerably lower in the informal than in the formal sector. Average earnings per month in the informal sector are just above 400 Reais per month (about 200 US $\$$ in year 2000), compared to 769 Reais $\left(\mathrm{R} \$\right.$ ) in the formal sector. At the $20^{\text {th }}$ percentile of the earnings distribution in the informal sector, earnings are $120 \mathrm{R} \$$ - well below the minimum wage (151 R\$) - compared to $221 \mathrm{R} \$$ at the same percentile in the formal sector. The fact that the earnings at the $20^{\text {th }}$ percentile in the formal sector are reached in the informal sector at approximately the 50th percentile shows that there is a considerable overlap in the earnings distributions in the two sectors. Second, education is lower in the informal sector. On average, a worker in the informal sector has 2.5 years less education than a worker in the formal sector. Similar to the distributions of income, there is an overlap in terms of education between the two sectors. For example, $27 \%$ of the workers in the informal sector have nine or more years of education, while almost $50 \%$ in the formal sector have less than nine years of education. Third, the share of workers who have just entered the labour market or are close to retirement is higher in the informal sector, even though this is not as pronounced as in many other countries (Perry, et al., 2007). One aspect in which Brazil deviates from many other examples is the gender distribution across the sectors. While the informal sector in many countries tends to be over-represented by women, there is no such gender bias in Brazil. In terms of industrial composition, there is a slight bias towards manufacturing and domestic services in the informal sector compared with the composition of the formal sector. 
There is a vast variation of informality in local labour markets. The average share of informality at municipal level is $55 \%$, but around this mean, informality varies between $20 \%$ and $80 \%$. There are more than 300 municipalities with shares below $30 \%$ and over 1100 with shares above $70 \%$. This degree of variation in informality is not altered much when small municipalities of 10000 or fewer inhabitants are excluded. Even among the 200 most populated municipalities - each with 400000 or more inhabitants - informality varies between $25 \%$ and $70 \%$.

\section{[Table 1]}

\subsection{Explanatory variables}

Table 2 gives an overview of the explanatory variables used in the empirical analysis. Human capital is represented by the individual's age and years of education. Squared age and education are included to test for non-linearity. Two additional variables are added to control for labour productivity: an indicator for physical or mental disability, which is likely to affect work ability, and an indicator showing if the worker has recently migrated from a rural area. It could be that people who have recently entered the urban labour force from rural areas face a disadvantage in terms of knowledge of the local economy and have less access to social networks and informal institutions, which affect labour productivity.

Variables included under the assumption that they affect the valuation of non-pecuniary benefits of informal-sector employment are: gender, position in the household, marital status, and indicators for the presence of formal-sector workers and young children in the household. Gender bias in household-related work and responsibilities may imply that women benefit more from the work flexibility in the informal sector than men. This effect may be strengthened if there are children in the household.

The variable for regional government effectiveness is developed by Jonasson (2011) and is based on the municipal data described above. It is constructed as an index and has similarities with the Brazilian IQIM index of local institutional quality used by the Brazilian Ministry of Planning. It also has similarities with the Worldwide Governance Indicators (Kaufmann, et al., 2009). A common 
feature of these measures is that they are constructed based on a range of indicators in order to obtain an index that can rank regions or countries according to quality of governance and institutions.

The composite variable government effectiveness $(G E)$ is given by the average of three indices that are constructed to capture different aspects of local governance and bureaucracy. The first component is policy formulation $\left(G E_{1}\right)$, which is a proxy for the capacity of the local administration to formulate and implement policy. It is based on 20 indicators, showing to what extent the municipality has councils, development plans, ordinances, and regulations in various domains such as education, urban development, employment, and property ownership. The second component represents bureaucratic resources $\left(G E_{2}\right)$ and is based on information about the employment form and competence of bureaucrats; the degree of co-ordination between units with different areas of responsibility; and information technology resources. The third component represents the quality of, and access to, public goods and services $\left(G E_{3}\right)$. This index is based on the teacher/pupil ratio in public primary schools, the number of health centres per municipality inhabitant, the degree of internet services offered to the public, the existence of public libraries, and the degree of support for helping people with housing. All index variables are between zero and one. The correlation coefficients of $G E_{1}, G E_{2}$, and $G E_{3}$, range between 0.24 and $0.42 .^{5}$ The effect of enforcement of tax and labour regulation, as discussed in the theoretical model, is not tested for explicitly since it is difficult to separate this from other qualities of the local bureaucracy $\left(G E_{2}\right)$.

A number of municipal control variables are included as well. The sectoral composition of the municipal economy is controlled for using the shares of agriculture, manufacturing, services, and public sector production in the total municipal gross product. While factors that affect informality may influence the structure of the local economy in the long run, the concern here is that the relative demand for informal labour may be higher in local economies where certain sectors dominate (such as agriculture or services). Average firm size (number of employees) in the formal sector is included to control for technology in the formal sector, under the assumption that labour is more productive in large firms, which would increase the expected income in the formal sector for any level of workerskill. A distance-weighted measure of local population size is included to control for market potential, assuming that the higher the market potential the higher the returns to acting formally. The share of 
rural-to-urban migrants in the labour force is added under the assumption that it will increase the relative supply of unskilled labour and drive down the labour income in the informal sector. Lastly, municipal product per capita is included to check to what extent the results remain robust while keeping income level constant.

[Table 2]

\subsection{Instrumental variables}

The instrumental-variable approach outlined in Section 4 is used in order to take into account this potential endogeneity of government effectiveness. Instrumental variable candidates are needed that are correlated with $G E$, yet uncorrelated with the error terms of the two models. Naritomi et al. (2007), who use governance as an indicator of institutional development in regions of Brazil, find that a set of geographical variables are significantly related to both economic and institutional development. Almeida and Carneiro (2009), who analyze the effect of labour regulation enforcement on informal employment, suspect that enforcement may be endogenous and use distance to the nearest enforcement office interacted with the local intensity of labour inspectors as an instrumental variable. Based on these studies, three geographical variables were chosen as instruments: longitude, latitude, and transportation cost to state capital from the seat of the municipality. The age of the municipality is included as a fourth instrumental variable. More than 1400 of Brazil's municipalities were created after the constitutional reform in 1988. There is some anecdotal evidence that some of these municipalities were partly created out of rent-seeking motives and that governance performance has developed quite poorly in some of these new municipalities (Economist, 2008; Instituto Brasileiro de Geografia e Estatística, 2001). When the government effectiveness variable, $G E$, is regressed on the instruments and the other exogenous municipal variables, all the instruments show a statistically significant conditional correlation with $G E$.

The validity of the instruments was checked with $\mathrm{F}$ tests of the hypothesis that all instrumental variables in an OLS estimation of model (16b) have zero coefficients. The critical F statistic given by Stock et al. (2002) is 9.08 for three instruments and 10.83 for five instruments. The F-statistic for the null hypothesis that the coefficients of the three geographical variables are jointly zero was 16.74 . As 


\section{Empirical results}

Table 3 contains the results of both the basic probit model and the IV probit model. The binary variable indicating whether the worker is employed in the informal sector (is) serves as the dependent variable in all specifications. Six specifications are reported, in which variables have been added stepwise to evaluate the validity of the hypotheses and assess the stability of the coefficient estimates as additional factors are controlled for. The coefficients show marginal effects of small changes in the independent variables or changes from zero to one for binary variables. Standard errors are adjusted to take into account clustering of the error term within municipalities. Due to the large sample size (more than 2 million observations), standard errors are still small after this adjustment and most of the coefficients are statistically significant at very high levels. Specific attention should therefore be given to the economic significance when interpreting the coefficient estimates.

The first column of Table 3 show results from a specification with only worker characteristics included. In line with the model prediction, human capital has a negative effect on the probability of working in the informal sector. Age has a negative but decreasing effect, while years of education appears to have a negative and increasing effect, as indicated by the coefficient estimates of the square terms of these variables. An increase in education by 2.5 years (which is the difference in average education between the two sectors) decreases the probability of informal employment by about six percentage points. This relationship remains stable across the specifications, as municipal-level variables are added.

In column 2, government effectiveness $(G E)$ is included in the model, but without any additional municipal control variables. The coefficient estimate is negative (in line with the predictions of the theoretical model) and statistically significant. The magnitude of -0.24 of the coefficient estimate implies that an increase of the index value of $G E$ by one standard deviation, from the average of 0.35 to 0.49 , while holding everything else constant, is associated with a decline in the 
probability of a worker being informally employed of about 3.5 percentage points. As a series of municipal control variables are added to the model, the $G E$ coefficient estimate shrinks to about -0.15 , but still significant at the 1-percent level (column 3).

To gain further insight into how government effectiveness might affect informality, the $G E$ index is decomposed into its three sub-components and included in the probit model. The results in column 4 suggest that resources for policy formulation $\left(G E_{1}\right)$ are less important than the quality of bureaucracy $\left(G E_{2}\right)$ and public service provision $\left(G E_{3}\right)$. One interpretation of these results relates to the patterns of public trust in politicians, as discussed in the beginning of the paper; political promises delivered by means of planning, regulation, and the creation of municipal ordinances may have little effect on citizens' incentives if they doubt that these political efforts will have any real effect on them (Saavedra and Tommasi, 2007). Quality of the bureaucracy and public services, on the other hand, might have a more direct effect on incentives in terms of actual enforcement of regulation and other value-added in the formal sector.

The only case in which the government effectiveness coefficient becomes statistically indistinguishable from zero is when municipal gross product per capita is included as a control variable (column 5). This suggests that the level of economic development has a more important effect on informality than government effectiveness. However, income per capita should probably be perceived, to a larger extent than any other control variable, as endogenously determined by other municipal characteristics. This potential endogeneity of the local income level calls for caution in the interpretation of the results when local income is included. ${ }^{6}$

Column 6 reports the results from one of all the IV probit specifications that were tested. This specification is based on the specification in column 3, with the difference that government effectiveness is instrumented for using the four instrumental variables discussed above. Exogeneity of $G E$ in this IV probit specification was rejected by a Wald test at the one-percent level, confirming the suspicion of endogeneity. The $G E$ coefficient remains negative and statistically significant, even though it is larger in magnitude (-0.46 instead of -0.15 in column 3$)$. Experiments with a series of other combinations of instrumental variables gave qualitatively similar results, even though the magnitude of the coefficients varied with specification. 
[Table 3]

A few observations might be warranted regarding the coefficients in Table 3 that are not part of the core hypotheses. Ten individual characteristics other than human capital proxies are included in the analysis. First, being female has a very small positive effect on the probability of being in the informal sector. This gender effect is notable only where there are young children in the household (according to the interaction coefficient). Among the coefficients of the local economy control variables $(z)$, it can be noted that the share of manufacturing in the local economy has a negative effect on informality. Except in one case, the share of agriculture and the relative size of the service sector show no significant relationship with informality (the excluded sector being the public sector). There is a positive relationship between informality and the share of the urban labour force that consists of recent rural-to-urban migrants (even when controlling for migrant status of the individual). Rural migrants are likely to increase the relative supply of low-skilled labour, drawn primarily to the informal sector. Lastly, the size of the local population has a small negative effect on informality, giving some support to the notion that there are higher returns to formality in larger markets. This could be due to greater opportunities for specialisation as well as economies of scale in production. Robustness checks discussed in the Online Appendix show that the coefficient estimates of main interest generally remain stable and significant with the expected sign. In cases where the sample size is reduced to a small subset, some deviation in the results is observed.

\section{Conclusion}

The aim of this paper is to assess how informal employment is affected by the extent to which the government supports and implements formal institutions and provides high-quality public goods and services, referred to here as government effectiveness. A simple theoretical model was outlined to discuss how this may be directly related to worker decisions and informal employment. The empirical assessment of the model supports the main hypotheses: informality is higher where education is lower 
and where governance is less effective. These results complement previous studies by showing that regional factors, which are exogenous to the individual, affect individual employment outcomes. They also complement cross-country studies by showing that regional differences at sub-national level may cause informality to vary just as much as between countries, despite the fact that the formal institutional framework is held constant.

The ambition of the paper is not to provide specific policy advice on which actions to take in order to reduce informal employment. Nevertheless, a conclusion from the empirical results is that human capital investment is the principal means of increasing the chances of workers to find formal employment and strengthening the incentives to choose formal employment. But the results also suggest that the incentive structure may go beyond economic returns to formalisation. For the local government, the most challenging task - besides providing education, efficient bureaucracy and other public services to its citizens - might be to improve the quality of the "social contract" between the authorities and citizens. This implies making participation in the formal sector the norm rather than an exception. While such norms are likely to change only slowly over time, a government can seek ways to improve the sense of political participation and inclusion among its citizens. This includes transparency in the political decision process and in the spending of public resources, as well as recognizing the needs of the people outside the formal sector just as much as the needs of those who are already in it.

\section{Endnotes}

\footnotetext{
${ }^{1}$ The assumption that the probability of finding a job in the formal sector depends on worker skill stems back to Fields (1975), who assumes that workers are employed in the "murky" (informal) sector while searching for jobs in the urban (formal) sector.

${ }^{2}$ Self-employed workers do not receive labour income from an employer, but get paid for their production of goods and services. For simplicity, assume that production among self-employed is given by $q=L^{I S}(s)$ and that the price of output equals one.

${ }^{3}$ Both in Figure 1 and Figure 2 the parameters $\alpha$ and $\beta$ are assumed, for simplicity, to sum to 1 ; hence the linearity of $y^{F S}$.
} 


\footnotetext{
${ }^{4}$ Henley et al. (2009) provide an analysis of three alternative measures of informal employment in Brazil, using the PNAD survey. The definition used here corresponds to a large extent to their measure of informality defined as "no signed labor card".

${ }^{5}$ As noted by Langbein and Knack (2010), the six Worldwide Governance Indicators show bivariate correlations between 0.64 and 0.91 .

${ }^{6}$ This is discussed as part of several robustness checks in the Online Appendix.
}

\section{References}

Almeida, R. and Carneiro, P. (2009) Enforcement of Labor Regulation and Firm Size. Journal of Comparative Economics, 37(1), pp. 28-46.

Bosch, M., Goni, E., and Maloney, W. (2007) The Determinants of Rising Informality in Brazil: Evidence from Gross Worker Flows. Washington, DC: World Bank Policy Research Working Paper 4375. The World Bank.

Casson, M., Della Giusta, M., and Kambhampati, U. (2010) Formal and Informal Institutions and Development. World Development, 38(2), pp. 137-141.

Chaudhuri, K., Schneider, F., and Chattopadhyay, S. (2006) The Size and Development of the Shadow Economy: An Empirical Investigation from States of India. Journal of Development Economics, 80(2), pp. 428-443.

de Paula, Á. and Scheinkman, J. (2010) Value-Added Taxes, Chain Effects, and Informality. American Economic Journal: Macroeconomics, 2 (4), pp. 195-221.

Economist. (2008) Real-politik: Why Elections, Even to Lowly Office, Are so Expensive. Economist, 388, September 27, pp 50-52.

Fajnzylber, P., Maloney, W., and Montes-Rojas, G. V. (2009) Releasing Constraints to Growth or Pushing on a String? Policies and Performance of Mexican Micro-Firms. Journal of Development Studies, 45(7), pp. 1027-1048.

Fields, G. (1975) Rural-Urban Migration, Urban Unemployment and Underemployment, and JobSearch Activity in LDCs. Journal of Development Economics, 2(2), pp. 165-187.

Freeman, R. (2009) Labor Regulations, Unions, and Social Protection in Developing Countries: Market Distortions or Efficient Institutions? Cambridge, MA: NBER Working Paper Series 14789. National Bureau of Economic Research.

Friedman, E., Johnson, S., Kaufmann, D., and Zoido-Lobaton, P. (2000) Dodging the Grabbing Hand: the Determinants of Unofficial Activity in 69 Countries. Journal of Public Economics, 76(3), pp. 459-493.

Funkhouser, E. (1996) The Urban Informal Sector in Latin America: Household Survey Evidence. World Development, 24(11), pp. 1737-1751. 
Galiani, S. and Weinschelbaum, F. (2010) Modeling Informality Formally: Households and Firms. La Plata: CEDLAS Working paper. Centro de Estudios Distributivos, Laborales y Sociales.

Glaeser, E., La Porta, R., Lopez-de-Silanes, F., and Shleifer, A. (2004) Do Institutions Cause Growth? Journal of Economic Growth, 9(3), pp. 271-303.

Gong, X., van Soest, A., and Villagomez, E. (2004) Mobility in the Urban Labor Market: A Panel

Data Analysis for Mexico. Economic Development and Cultural Change, 53(1), pp. 1-36.

Hall, R. and Jones, C. (1999) Why do some countries produce so much more output per worker than others? Quarterly Journal of Economics, 114(1), pp. 83-116.

Hansen, H., Rand, J., and Tarp, F. (2009) Enterprise Growth and Survival in Vietnam:

Does Government Support Matter? Journal of Development Studies, 45(7), 1048-1069.

Henley, A., Arabsheibani, R., and Carneiro, F. (2009) On Defining and Measuring the Informal Sector: Evidence from Brazil. World Development, 37(5), pp. 992-1003.

Instituto Brasileiro de Geografia e Estatística. (2001, April 17). IBGE traça o perfil administrativo de todos os municípios brasileiros. Retrieved June 2, 2011, from http://www1.ibge.gov.br/home/presidencia/noticias/1704munic.shtm

Johnson, S., Kaufmann, D., and Zoido-Lobaton, P. (1998) Regulatory Discretion and the Unofficial Economy. American Economic Review, 88(2), pp. 387-392.

Jonasson, E. (2011) Informal Employment and the Role of Regional Governance. Review of Development Economics, forthcoming.

Jütting, J., Parlevliet, J., and Xenogiani, T. (2008) Informal Employment Re-loaded. Paris: OECD Development Centre Working Paper 266. OECD Development Centre.

Kaufmann, D., Kraay, A., and Mastruzzi, M. (2009) Governance Matters VIII: Aggregate and Individual Governance Indicators 1996-2008. Washington, DC: Policy Research Working Paper 4978. World Bank.

Kucera, D. and Xenogiani, T. (2009) Persisting Informal Employment: What Explains It? In J. Jütting \& J. de Laiglesia (eds), Is Informal Normal? Towards More and Better Jobs in Developing Countries, pp. 63-88. (Paris: OECD)

Langbein, L. and Knack, S. (2010) The Worldwide Governance Indicators: Six, One, or None? Journal of Development Studies, 46(2), pp. 350-370.

Loayza, N. (1996) The Economics of the Informal Sector: A Simple Model and Some Empirical Evidence from Latin America. Carnegie-Rochester Conference Series on Public Policy, 45, pp. 129-162.

Loayza, N., Oviedo, A. M., and Servén, L. (2006) The Impact of Regulation on Growth and Informality: Cross-Country Evidence. In B. Guha-Khasnobis, R. Kanbur, and E. Ostrom (eds), Linking the Formal and Informal Economy: Concepts and Policies, pp. 121-144. (Oxford: Oxford University Press) 
Loayza, N. and Rigolini, J. (2011) Informal Employment: Safety Net or Growth Engine? World Development, forthcoming.

Loayza, N., Servén, L., and Sugawara, N. (2010) Informality in Latin America and the Caribbean. In N. Loayza and L. Servén (eds), Business Regulation and Economic Performance: A Latin American Perspective, pp. 157-196. (Washington, DC: The World Bank)

Maloney, W. (2004) Informality Revisited. World Development, 32(7), pp. 1159-1178.

Marcouiller, D., Ruiz de Castilla, V., and Woodruff, C. (1997) Formal Measures of the InformalSector Wage Gap in Mexico, El Salvador, and Peru. Economic Development and Cultural Change, 45(2), pp. 367-392.

Naritomi, J., Soares, R., and Assuncão, J. (2007) Rent Seeking and the Unveiling of 'de facto' Institutions: Development and Colonial Heritage within Brazil. Cambridge, MA: NBER Working Paper 13545. National Bureau of Economic Research.

Perry, G., Maloney, W., Arias, O., Fajnzylber, P., Mason, A., and Saavedra-Chanduvi, J. (2007) Informality: Exit and Exclusion. Washinton, D.C.: The World Bank.

Rauch, J. (1991) Modelling the Informal Sector Formally. Journal of Development Economics, 35 (1), pp. 33-47.

Saavedra, J. and Tommasi, M. (2007) Informality, the State and the Social Contract in Latin America: A Preliminary Exploration. International Labour Review, 146(3-4), pp. 279-309.

Schneider, F. and Enste, D. (2000) Shadow Economies: Size, Causes, and Consequences. Journal of Economic Literature, 38(1), pp. 77-114.

Stock, J., Wright, J., and Yogo, M. (2002) A Survey of Weak Instruments and Weak Idenification in Generalized Method of Moments. Journal of Business and Economic Statistics, 20(4), pp. 518529.

Straub, S. (2005) Informal Sector: The Credit Market Channel. Journal of Development Economics, 78(2), pp. 299-321.

Torgler, B. and Schneider, F. (2007) Shadow Economy, Tax Morale, Governance and Institutional Quality: A Panel Analysis. Bonn: IZA Discussion Paper Series 2563. Institute for the Study of Labor.

Torgler, B. and Schneider, F. (2009) The impact of tax morale and institutional quality on the shadow economy. Journal of Economic Psychology, 30(2), pp. 228-245. 
Table 1. The urban labour market in Brazil

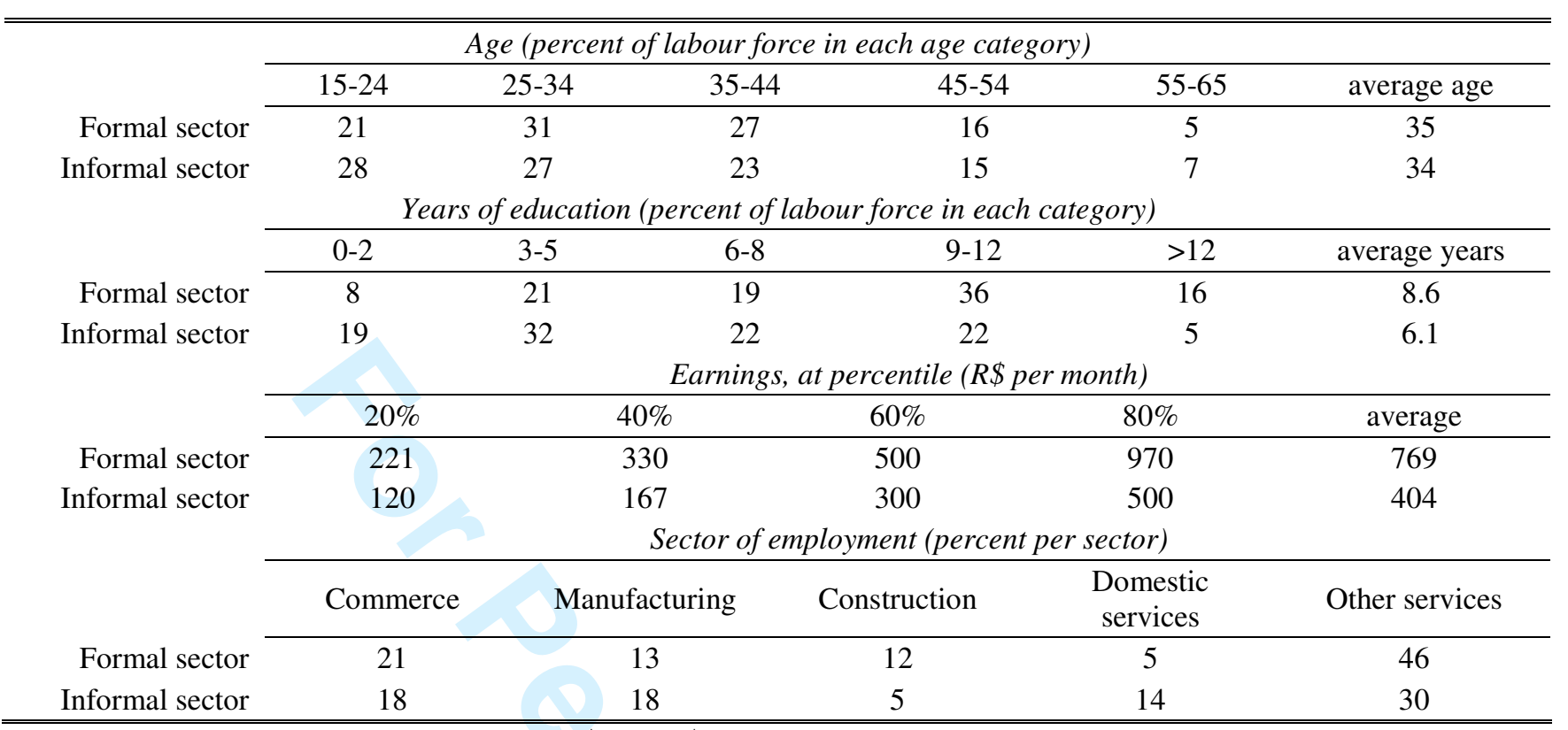

Note: In August 2000, the exchange rate was R \$1 = US\$0.56. Source: Brazilian Demographic Census, 2000. 
Table 2. Variables used in the empirical analysis

\begin{tabular}{|c|c|c|c|}
\hline Variable & Mean & S.D. & Definition \\
\hline \multicolumn{4}{|c|}{ Worker level $(N=2,222,387)$} \\
\hline Informal employment & 0.436 & 0.496 & $\begin{array}{l}\text { Individual works in informal sector, with earned non-zero } \\
\text { income }\end{array}$ \\
\hline Age & 34.5 & 11.6 & Individual's years of age \\
\hline Education & 7.5 & 4.3 & Individual's years of schooling \\
\hline Gender - female & 0.397 & 0.489 & Individual is female \\
\hline Household head & 0.516 & 0.500 & Individual is household head \\
\hline Married & 0.454 & 0.498 & Individual is married \\
\hline Race - black & 0.066 & 0.248 & Individual is black \\
\hline Disabled & 0.021 & 0.144 & Individual has reported physical or mental problem \\
\hline Rural-urban migrant & 0.029 & 0.169 & Individual has moved recently from a rural area \\
\hline Children in household & 0.480 & 0.500 & There is at least one child in the household, $<10$ years old \\
\hline \multicolumn{4}{|c|}{ Municipal level $(N=5,506)$} \\
\hline Share informal employment & 0.554 & 0.161 & $\begin{array}{l}\text { Share of the urban municipal labour force that has informal } \\
\text { employment. }\end{array}$ \\
\hline Average education & 6.4 & 1.1 & Average years of education in the municipal labour force. \\
\hline \multicolumn{4}{|l|}{ Municipal variables } \\
\hline Government effectiveness, $G E$ & 0.348 & 0.139 & $\begin{array}{l}\text { Index composed of } G E_{1}, G E_{2} \text {, and } G E_{3} \text {, below, to represent } \\
\text { government effectiveness in the municipality. }\end{array}$ \\
\hline Policy formulation, $G E_{1}$ & 0.253 & 0.183 & $\begin{array}{l}\text { Index composed of } 20 \text { variables to represent the capacity of the } \\
\text { municipal government to formulate and implement policy. }\end{array}$ \\
\hline Bureaucratic resources, $G E_{2}$ & 0.427 & 0.131 & $\begin{array}{l}\text { Index that represents the human, technical, and managerial } \\
\text { resources available to the municipal bureaucracy. }\end{array}$ \\
\hline Public goods, $G E_{3}$ & 0.363 & 0.234 & $\begin{array}{l}\text { Index composed of } 10 \text { variables to represent the quality of, and } \\
\text { access to, public goods in the municipality. }\end{array}$ \\
\hline Share agriculture & 0.232 & 0.163 & Agriculture as share of gross municipal product. \\
\hline Share manufacturing & 0.163 & 0.157 & Manufacturing as share of gross municipal product. \\
\hline Share services & 0.399 & 0.094 & Services as share of gross municipal product. \\
\hline Share public sector & 0.207 & 0.084 & Public sector production share of gross municipal product. \\
\hline Average firm size & 5.4 & 5.7 & Average number of employees in registered businesses. \\
\hline Local population & 694 & 1,464 & Local population estimate (thousands), weighted by distance \\
\hline Gross product per capita & 4,435 & 5,699 & Municipal gross product per capita, $\mathrm{R} \$$, year 2000 . \\
\hline Share rural immigrants & 0.056 & 0.047 & $\begin{array}{l}\text { Share of the urban labour force consisting of workers who have } \\
\text { migrated from a rural area, five years or less prior to the survey. }\end{array}$ \\
\hline \multicolumn{4}{|l|}{ Instrumental variables } \\
\hline Latitude & -16 & 8 & Latitude of municipal seat \\
\hline Longitude & -46 & 6 & Longitude of municipal seat \\
\hline Transport cost to state capital & 469 & 409 & Transportation cost from municipal seat to state capital city \\
\hline Age of municipality & 55 & 57 & Years since the municipality was created \\
\hline
\end{tabular}

Sources: Individual-level variables and informal employment and labour force skill on municipal level - Brazilian Demographic Census, 2000. Municipal variables for government effectiveness and the local economy - Gestão Pública, 2005-2006, and Base de Informações Municipais, 2000. 
Table 3. Empirical results: probability of informal employment.

\begin{tabular}{|c|c|c|c|c|c|c|}
\hline & (1) & (2) & (3) & (4) & (5) & (6) IV \\
\hline \multicolumn{7}{|l|}{ Human capital (s) } \\
\hline Age & $-0.023 * * *$ & $-0.022 * * *$ & $-0.022 * * *$ & $-0.022 * * *$ & $-0.022 * * *$ & $-0.022 * * *$ \\
\hline Age, squared & $0.000 * * *$ & $0.000 * * *$ & $0.000 * * *$ & $0.000 * * *$ & $0.000 * * *$ & $0.000 * * *$ \\
\hline Education & $-0.029 * * *$ & $-0.026^{* * *}$ & $-0.024 * * *$ & $-0.024 * * *$ & $-0.022 * * *$ & $-0.022 * * *$ \\
\hline Education, squared & $-0.000 * * *$ & $-0.000 * * *$ & $-0.000 * * *$ & $-0.000 * * *$ & $-0.001 * * *$ & $-0.000 * * *$ \\
\hline \multicolumn{7}{|l|}{ Other individual characteristics $(x)$} \\
\hline Gender - female & $0.007^{* *}$ & $0.008 * * *$ & $0.008 * * *$ & $0.008 * * *$ & $0.007 * *$ & $0.009 * * *$ \\
\hline Household head & $-0.031 * * *$ & $-0.031 * * *$ & $-0.033^{* * *}$ & $-0.033^{* * *}$ & $-0.033^{* * *}$ & $-0.032 * * *$ \\
\hline Married & $-0.052 * * *$ & $-0.056^{* * *}$ & $-0.053 * * *$ & $-0.052^{* * *}$ & $-0.051 * * *$ & $-0.053 * * *$ \\
\hline Race - black & $-0.012 * * *$ & $-0.008 * * *$ & $-0.007 * *$ & $-0.006^{* *}$ & $-0.008 * *$ & $-0.007 * *$ \\
\hline Disabled & $0.052 * * *$ & $0.050 * * *$ & $0.048 * * *$ & $0.048 * * *$ & $0.046 * * *$ & $0.045^{* * *}$ \\
\hline Rural-urban migrant & $0.030 * * *$ & $0.020 * * *$ & $0.009 * *$ & $0.009 * *$ & $0.013 * * *$ & $0.013 * *$ \\
\hline Children in household & $0.018 * * *$ & $0.015 * * *$ & $0.012 * * *$ & $0.012 * * *$ & $0.008 * * *$ & $0.009 * * *$ \\
\hline Female $\times$ child in hhd & $0.047 * * *$ & $0.047 * * *$ & $0.046 * * *$ & $0.046^{* * *}$ & $0.047 * * *$ & $0.046^{* * *}$ \\
\hline $\begin{array}{l}\text { Government effectiveness } \\
\text { Government effectiveness, } G E\end{array}$ & & $-0.244 * * *$ & $-0.153 * * *$ & & 0.004 & $-0.463^{* *}$ \\
\hline Policy formulation, $G E_{1}$ & & & & -0.021 & & \\
\hline Bureaucratic resources, $G E_{2}$ & & & & $-0.114^{* * *}$ & & \\
\hline Public goods, $G E_{3}$ & & & & $-0.047 * * *$ & & \\
\hline $\begin{array}{l}\text { Municipal control variables }(z) \\
\text { Gross product per capita }\end{array}$ & & & & & $-0091 * * *$ & \\
\hline Share agriculture & & & -0.116 & -0.106 & -0.041 & $-0.368 *$ \\
\hline Share manufacturing & & & $-0.283^{* * *}$ & $-0.284 * * *$ & $-0.165^{* *}$ & $-0.399 * * *$ \\
\hline Share services & & & -0.022 & -0.019 & $-0.120 * *$ & -0.136 \\
\hline Average firm size & & & -0.000 & -0.000 & 0.002 & 0.002 \\
\hline Share rural immigrants & & & $0.263^{*}$ & $0.253^{*}$ & $0.247 * *$ & -0.067 \\
\hline Local population & & & $-0.018 * * *$ & $-0.018^{* * *}$ & $-0.010 * * *$ & $-0.016^{* * *}$ \\
\hline Sample size & $2,220,387$ & $2,218,167$ & $2,213,429$ & $2,213,429$ & $2,213,429$ & $2,213,429$ \\
\hline McFadden pseudo $\mathrm{R}^{2}$ & 0.0728 & 0.0785 & 0.0846 & 0.0848 & 0.0890 & \\
\hline
\end{tabular}

Note: Dependent variable is the dummy variable indicating informal employment (is). Coefficients show marginal effects. Asterisks denote level of significance: $* * * 1 \%, * * 5 \%$, and $* 10 \%$. Standard errors are adjusted for error term clustering. Coefficient estimates that are reported as " 0.000 ", and yet statistically significant, are smaller than 0.0005 in absolute magnitude. Column 6 contains results from an IV specification, in which $G E$ is instrumented for. 
Figure 1. Skill thresholds equating expected earnings in the formal and informal sectors

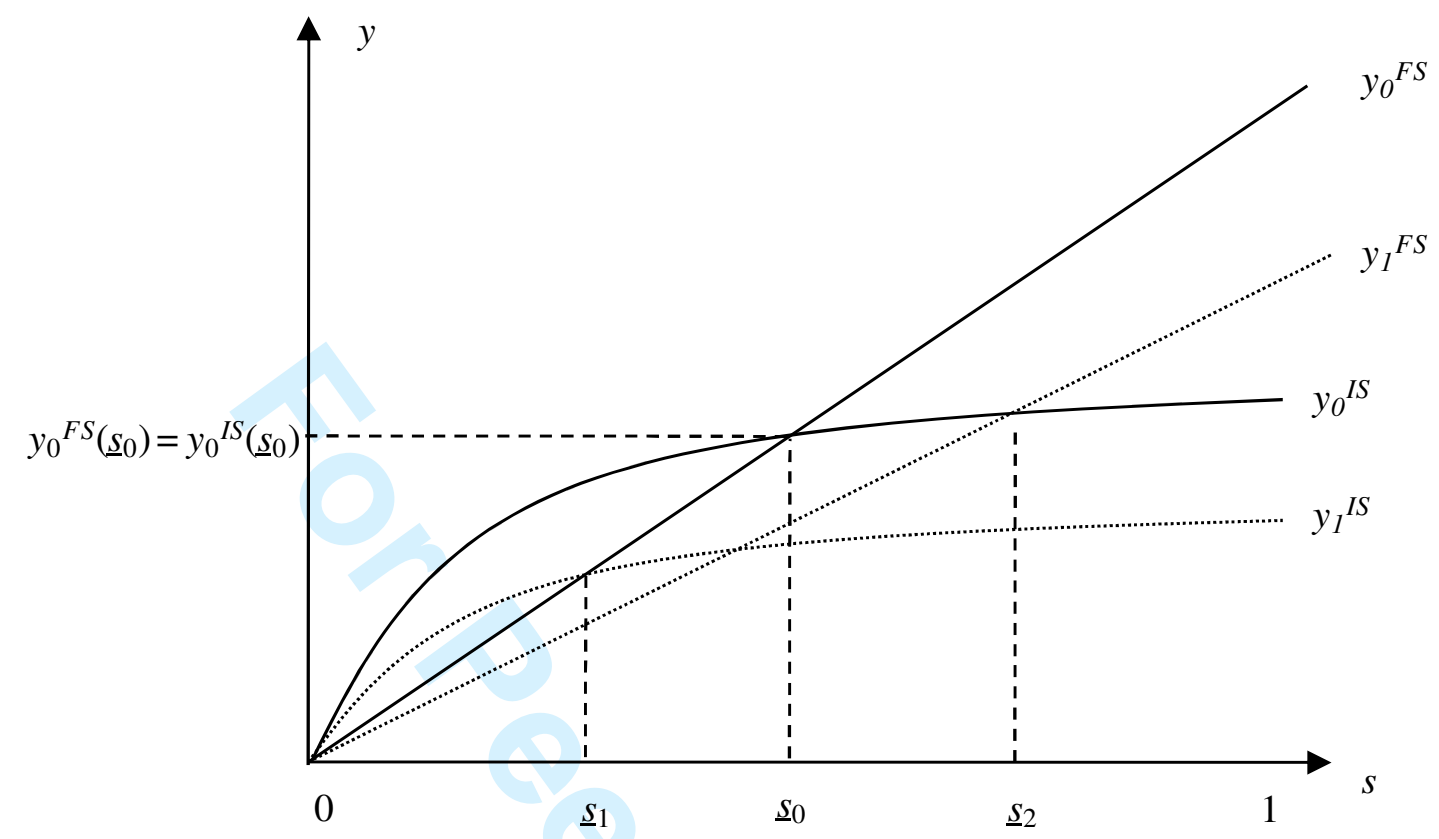

Figure 2. Skill thresholds in the presence of non-pecuniary costs and benefits in the informal sector

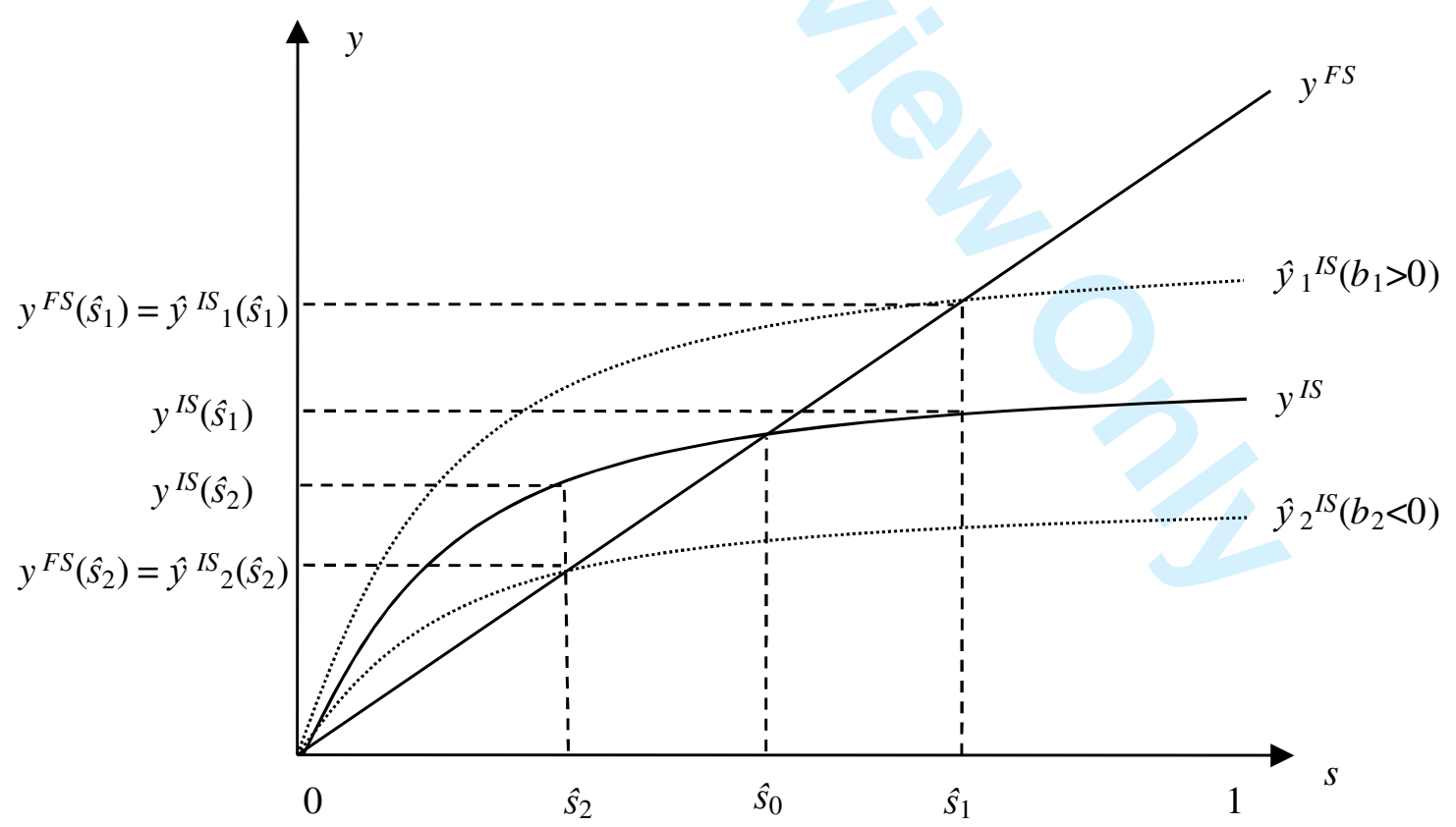




\section{Online Appendix to \\ "Government Effectiveness and Regional Variation in Informal Employment":}

\section{Robustness of the empirical results}

Some further endogeneity concerns and limitations of the empirical results are elaborated on briefly in this appendix. First, per-capita income, as a general indicator of local economic development, is likely to affect - and be affected by - several observable and unobservable variables (including quality of governance). Due to this potential endogeneity, it is included only in one specification of each model. This resulted in a statistically insignificant coefficient estimate of the governance index. To assess the importance of the municipal key variables while still holding local per-capita income "constant", the models were evaluated on a sub-sample of municipalities with relatively homogenous income. A 40percent sub-sample of municipalities, consisting of the approximately 2100 "middle-income municipalities" with per-capita income of between 2000 and $5000 \mathrm{R} \$$, was selected for this purpose. While coefficient estimates change slightly in magnitude, no qualitative changes occur with this subsample. A tentative conclusion is that the results are not driven to any large extent by differences in productivity or per-capita income.

Second, the structure of the local economy could be endogenously determined in the model, just as governance might be. The structure of the local economy could be affected by human capital intensity, institutional and economic development, geography, or by unobserved characteristics. The models were therefore evaluated on sub-samples with relatively homogenous structures of the local economy. While municipalities dominated by services and manufacturing do not deviate from the previously obtained results, agriculture-dominated municipalities do not show the same strong relationships between informality and governance.

Third, the empirical literature on spatial human capital externalities is usually concerned about endogenous sorting of skilled people to certain regions (Moretti, 2004). Thus the average level of human capital in a city or region might not be exogenously determined. While beyond the scope of this study to 
fully adjust for this possible endogeneity (by the means of additional instrumental variables), the method of evaluating the models on sub-samples has been applied. By using the sub-sample of individuals who have never moved from one municipality to another, some of the endogenous-sorting problem is taken care of. Even if the resulting sample size decreases by half, the key coefficient estimates remain robust, with only minor changes in magnitude. Another sub-sample includes only municipalities with relatively homogenous education (those less than half a standard deviation away from the average level of education). Parameter estimates from regressions on this sample are similar to those on the full sample, with the exception for two of the disaggregated governance indices in some of the specifications.

Fourth, in the results discussed above there is no distinction made between the self-employed and employees in the informal sector. While these two groups are treated as homogenous in this study, they might face different income prospects and hence different incentives regarding sector choice. Some empirical studies focus solely on employees (Pratap and Quintin, 2006) or self-employed (Blau, 1985) in the informal sector, due to their potentially fundamental differences. No major deviations in the results are observed when the probit model is estimated on sub-samples with a) all informal employees excluded and b) with all informal self-employed excluded.

In sum, the robustness checks show that the coefficient estimates of main interest generally remain stable and significant with the expected sign. In cases where the sample size is reduced to a small subset, some deviation in the results is observed.

\section{References}

Blau, D. (1985) Self-Employment and Self-Selection in Developing Country Labor Markets. Southern Economic Journal, 52(2), pp. 351-363.

Moretti, E. (2004) Human Capital Externalities in Cities. In V. Henderson and J.-F. Thisse (eds), Handbook of Regional and Urban Economics, Vol. 4, pp. 2243-2291. (Amsterdam: Elsevier Science)

Pratap, S. and Quintin, E. (2006) Are labor markets segmented in developing countries? A semiparametric approach. European Economic Review, 50(7), pp. 1817-1841. 